\title{
A FUZZY LOGIC-BASED MODEL FOR ANALYSIS AND EVALUATION OF SERVICES IN A MANUFACTURING COMPANY
}

\author{
Leon Oblak* \\ University of Ljubljana, Biotechnical Faculty, Ljubljana, Slovenia \\ Manja Kitek Kuzman \\ University of Ljubljana, Biotechnical Faculty, Ljubljana, Slovenia \\ Petra Grošelj \\ University of Ljubljana, Biotechnical Faculty, Ljubljana, Slovenia
}

In an increasingly competitive market, companies must look for new ways to gain competitive advantage. One of these ways is the provision of services. This article presents a multicriteria model for analysis and evaluation of services in a manufacturing company. We divided the services that the manufacturing company can offer to its customers into pre-sales, sales and after-sales services. In the second phase we developed a specific model for the furniture industry. The model was tested with information obtained in a survey by eight kitchen manufacturers from four European countries and was applied to determine the level of services offered. Results have shown that the model can be a useful tool when evaluating the competitiveness of individual manufacturing companies in terms of service provision. Based on the results, companies can develop their business strategies to meet the needs and expectations of potential customers from this perspective as well.

Key words: Manufacturing company, Customer, Services, Service economy, Product

\section{INTRODUCTION}

In developed market economies, the service industry is already generating approximately three quarters of gross domestic product and employing about two thirds of the working population. Analysts (Buera \& Kaboski, 2012; Grönroos \& Ojasalo, 2004; Gummesson, 1998, 2014; Hoekman \& Mattoo, 2012; Jones, 1988) predict that the ratio between the manufacturing and the service industry will continue to change in favor of the latter.

Services are usually performed and used at the same time, changing quickly, transient and cannot be stored. For this reason, many authors (Brady \& Cronin, 2001; Cronin Jr \& Taylor, 1992; Gummesson, 1991; McLaughlin \& Coffey, 1990; Muyeed, 2012; Sahay, 2005; Schembri \& Sandberg, 2002; Zeithaml, 2000) believe that it is extremely difficult to determine and monitor service quality. We cannot measure it precisely and the sole criterion of quality is customer satisfaction with the service, which is closely linked to customer ex- pectations (Santouridis \& Trivellas, 2010). One of the attempts to measure customer satisfaction by multiple indicators is with various customer satisfaction indexes (Ahn \& Sohn, 2009; Johnson et al., 2001; Nabavi et al., 2014; Sun \& Kim, 2013). The quality of service changes depending on where, when and by whom it is carried out. To maintain or gain new customers, each manufacturing company must complement its product range with service activities. In recent years, it has become increasingly clear that companies that do not include good services in marketing their products cannot strengthen their competitive position on the markets. Companies that do not offer services and companies with poor services eventually lose even the most loyal customers (Ahn \& Sohn, 2009; Brax, 2005; Murali et al., 2016b).

Many authors (Ahmad \& Butt, 2012; Alzola \& Robaina, 2010; Godley, 2013; Kasper \& Lemmink, 1989; Posselt \& Gerstner, 2005) divide services into pre-sales services and after-sales services, but the best way to nail customer service is to 
think of the customers' experience before, during and after their purchase. So, services that can be provided by a manufacturing company to customers can be divided into pre-sales services, sales services and after-sales services. Marketers need to develop a set of services that will support the products sold by the company in such a way that they will satisfy the customers better than the competitors. Good pre-sales services, sales services and after-sales services are the key to customer retention. Consumers will not make a repeat purchase or continue with a company's services if they have a bad experience.

If a manufacturing company wants to be successful in the field of services offered, it must establish a system for performance monitoring. This means that the company regularly reviews and evaluates its services and the services of its competitors. These assessments can be quantitative or qualitative. Quantitative advantages can be easily measured. Qualitative benefits of services relate mainly to the quality of the service performed, rated by customers according to their expectations, and the actual results of the services. Quality of service can thus be defined as the difference between the expected and the actual service, as perceived by the customer. It is essential to emphasize that customer expectations vary, but in general, the level of service quality expected by customers is constantly increasing.

The aim of this study is to develop a new model that will enable the measurement of performed services. It should enable the incorporation of qualitative and quantitative information, measurable and unmeasurable data, and tangible and intangible opinions, experiences and judgments of customers and experts. There are numerous multicriteria decision methods that are widely used as part of decision support systems (Chai et al., 2013; Ho et al., 2010; Pezdevšek Malovrh et al., 2016; Zavadskas \& Turskis, 2011). We decided to build a model on the mathematical foundations of fuzzy sets that support the integration of imprecise information about real-world complex problems in a consistent way (Ratnayake, 2014).

The paper is organized as follows. In Section 2 a literature review of existing models for service evaluation is carried out and a new model is developed. Then a brief introduction to applied methods, namely the analytic hierarchy process and fuzzy logic approach, and an overview of literature employing these two concepts are provided in Section 3. In Section 4 the general model is adopted for the furniture industry. Section 4 presents the results of the evaluation of eight kitchen manufacturers from four European countries and offers a discussion on the model and the results. In Section 6 some conclusions are drawn.

\section{MODEL DEVELOPMENT}

The growth of the service economy presents great challenges for manufacturing companies. The increased importance of service industries has stimulated interest in productivity measures for this sector of the economy. There are numerous options for measuring the performance of services used by a company to determine what bothers the customers and what could be improved, such as a book of comments and complaints, customer surveys, covert or comparison shopping for services and similar activities. However, none of these activities explicitly show how successful the company is when offering service activities. Service companies must develop creative ways to fund their distinctive advantages. To create a successful service offering, managers need to determine which attributes to target for excellence and which to target for inferior performance. These choices should be heavily informed by the needs of customers. Managers should discover the relative importance customers place on attributes and then match the investment in excellence with those priorities (Frei, 2008)

There are several attempts in literature to develop a model for measuring services, especially aftersales services. Fuzzy clustering and the association rule was applied by Ahn and Sohn (2009) to identify customer groups and the importance of after-sales services for them. Multiple regression analysis was used by Murali et al. (2016b) in the analysis of the influence of after-sales services on customer satisfaction, customer retention and customer loyalty. Gaiardelli et al. (2007) proposed an integrated framework based on indicators of customer satisfaction and metrics evaluation of several activities for the after-sales network performance measurement in automotive companies. Several authors performed statistical studies to investigate whether after-sales 
service quality has an impact on customer satisfaction (Fazlzadeh et al., 2011; Murali et al., 2016a; Rigopoulou et al., 2008; Shaharudrn et al., 2009; Shahrouzifard \& Faraji, 2016). Qualitative and quantitative analysis in after-sales services using quality function deployment was carried out by Pakdil et al. (2012). However, the results of the literature review show that there is no model that incorporates the measurement of the whole spectrum of pre-sales, sales and after-sales services.
The aim of this study was to develop a general model that would enable companies to review and analyze this segment of business. We consider fuzzy and multicriteria decision methods to assess the performance of companies' services as a good foundation for such a model. In this study we proposed a four-stage model for the evaluation of companies' services that is based on fuzzy logic and the analytic hierarchy process (Figure 1).

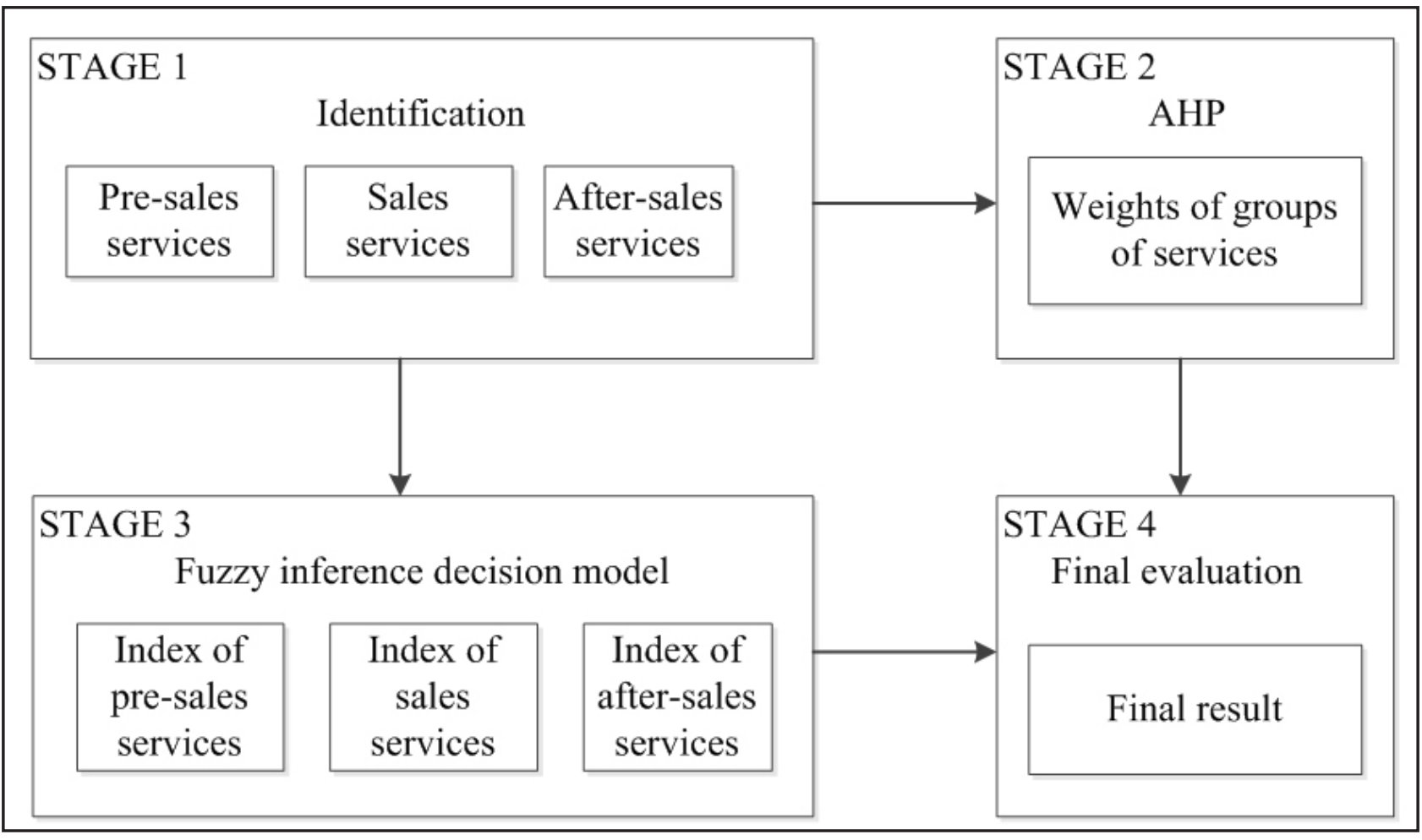

Figure 1: A four-stage model for service evaluation

In the first stage, pre-sales services, sales services and after-sales services should be identified. Pre-sales services are a set of activities normally carried out before a customer is acquired. They can offer extra content or merchandise that would normally be of a high price for free, thereby increasing the perceived value of this product. Sales services are services that the company carries out during the consumer buying decision process. They relate mainly to the payment facilities offered by the company to customers. After-sales services consist, among other things, of delivery, warranty, technical advice, product upgrading, repair and spare parts delivery (Ahn \& Sohn, 2009; Saccani et al., 2006).
In the second stage, the importance of groups of services should be determined. We selected the analytic hierarchy process (AHP) to perform this task. AHP is a widely used hierarchical multicriteria methodology for prioritizing alternatives that enables comparisons of quantitative and qualitative elements (Saaty \& Vargas, 2007). In the third stage, a fuzzy logic inference decision system (FIS) is applied to evaluate each group of services separately. FIS enables the modeling of complex and uncertain systems with soft data and imprecise information (Gharibi et al., 2012; Zadeh, 1965). The results of the third stage are indexes of all three groups of services. In the final stage, the results of AHP and the fuzzy model 
are aggregated into the final evaluation of services.

The presented model is sufficiently universal that it can be applied in many areas of sales. It enables the inclusion of only one or two groups of services instead of all three in the model. In stage two, any other group method for ranking objects can be employed. We suggested the AHP method as we believe that AHP is one of the most suitable methods for preference analysis of a group of objects. It enables the comparison of pairs of objects rather than ranking the entire group simultaneously. Measurable and unmeasurable objects can be compared. The method has strong mathematical and psychological foundations (Ananda \& Herath, 2003; Saaty \& Ozdemir, 2003). In stage three, we employed FIS as it is suitable for modeling the human thinking process and can handle uncertainties, impreciseness and vagueness of data and judgments in complex real-world systems (Afrinaldi \& Zhang, 2014; Nilashi et al., 2015). Nevertheless, any other multicriteria method for evaluation can be applied in stage three.

To demonstrate the employability of the developed model we adapted it to the furniture industry and presented it in Section 4. But first we revise the basis of AHP and FIS in the next section.

\section{METHODS}

\section{AHP}

To define the importance of groups of services the analytic hierarchy process (AHP) (Saaty, 1980 ) is applied in this study. AHP has also been used in numerous applications in supplier and vendor selection (Koul \& Verma, 2011; Luzon \& El-Sayegh, 2016; Noorul Haq \& Kannan, 2006; Yadav \& Sharma, 2015). In AHP, the objects are pairwise compared using a 1-9 AHP scale and comparison matrix $A$ of $n$ compared objects is constructed:

$$
A=\left[\begin{array}{cccc}
1 & a_{12} & \cdots & a_{1 n} \\
\frac{1}{a_{12}} & 1 & \cdots & a_{2 n} \\
\vdots & \vdots & \ddots & \vdots \\
\frac{1}{a_{1 n}} & \frac{1}{a_{2 n}} & \cdots & 1
\end{array}\right]
$$

1) Similarly to our model, FIS has been applied in
models for evaluating the performance level of
several fields (Nadali et al., 2011; Nilashi et al.,
2015). A combination of AHP and FIS has also
been employed in several applications (Carreño
Similarly to our model, FIS has been applied in
models for evaluating the performance level of
several fields (Nadali et al., 2011; Nilashi et al.,
2015). A combination of AHP and FIS has also
been employed in several applications (Carreño

Similarly to our model, FIS has been applied in
models for evaluating the performance level of
several fields (Nadali et al., 2011; Nilashi et al.,
2015). A combination of AHP and FIS has also
been employed in several applications (Carreño

Similarly to our model, FIS has been applied in
models for evaluating the performance level of
several fields (Nadali et al., 2011; Nilashi et al.,
2015). A combination of AHP and FIS has also
been employed in several applications (Carreño

Similarly to our model, FIS has been applied in
models for evaluating the performance level of
several fields (Nadali et al., 2011; Nilashi et al.,
2015). A combination of AHP and FIS has also
been employed in several applications (Carreño

The weights, , of compared objects are derived from comparison matrix $A$ by the eigenvector method:

$$
A w=\lambda_{\max } w
$$

with as the principal eigenvalue of comparison matrix $A$. The consistency of comparisons is measured by the consistency ratio $\mathrm{CR}$,

$$
C R=\frac{\lambda_{\max }-n}{(n-1) R I}
$$

where denotes a random index. According to Saaty (2006), is considered acceptable. The geometric mean (Saaty \& Peniwati, 2008) is applied to aggregate individual judgments into group judgments.

\section{A FUZZY LOGIC APPROACH}

Fuzzy logic was first introduced by Zadeh (1965). FIS has been used in many applications since then. It has been applied in

- environmental models including:

- waste management (Vesely et al., 2016)

- forecasting air quality (Carbajal-Hernández et al., 2012a; Fisher, 2006; Sowlat et al., 2011)

- water quality (Carbajal-Hernández et al., 2012b; Che Osmi et al., 2016; Gharibi et al., 2012; Ocampo-Duque et al., 2006)

- models for performing risk assessment (Camastra et al., 2015; Jamshidi et al., 2013; Rodríguez et al., 2016)

- in the field of manufacturing and sales for supporting customers' requirements (Juang et al., 2007)

- forecasting automobile sales (Wang et al., 2011)

- stock price prediction (Chang \& Liu, 2008)

- supplier selection (Lima Junior et al., 2013)

- measuring customer satisfaction (Zani et al., 2013). Journal of Applied Engineering Science 15(2017)3, 439 
et al., 2011; Donevska et al., 2011; Nilashi et al., 2015; Rodríguez et al., 2016).

A fuzzy logic inference system is a process from a given input of empirical values to an output including three main parts (Carbajal-Hernández et al., 2012b; Jamshidi et al., 2013; Ocampo-Duque et al., 2006; Ross, 2004): (1) membership functions; (2) fuzzy set operations; (3) IF-THEN inference rules. A Mamdani-type inference system (Mamdani \& Assilian, 1975) is used in our model because of the more intuitive and human-like nature of its rules compared to other types (Che Osmi et al., 2016; Kovac et al., 2012).

A fuzzy set $A$ is defined as a set of ordered pairs:

$A=\left\{\left(x, \mu_{A}(x)\right) \mid x \in X\right\}, \mu_{A}(x): \mathrm{X} \rightarrow[0,1]$,

where is a membership function of $\mathrm{x}$ in $\mathrm{A}$ and $\mathrm{X}$ is the universe of discourse. The element $x$ can only partly belong to the fuzzy set $A$. The grade of membership in fuzzy set $A$ is determined by the value of the membership function. Membership functions can have different shapes such as triangular, trapezoidal or Gaussian. Linear membership functions are easier to use and provide good performance (Carbajal-Hernández et al., 2012b). For the purpose of this study, trapezoidal membership functions (Figure 2) are selected and presented as:

$\mu(x ; a, b, c, d)=\min \left\{\frac{x-a}{b-a}, 1, \frac{d-x}{d-c}\right\}$

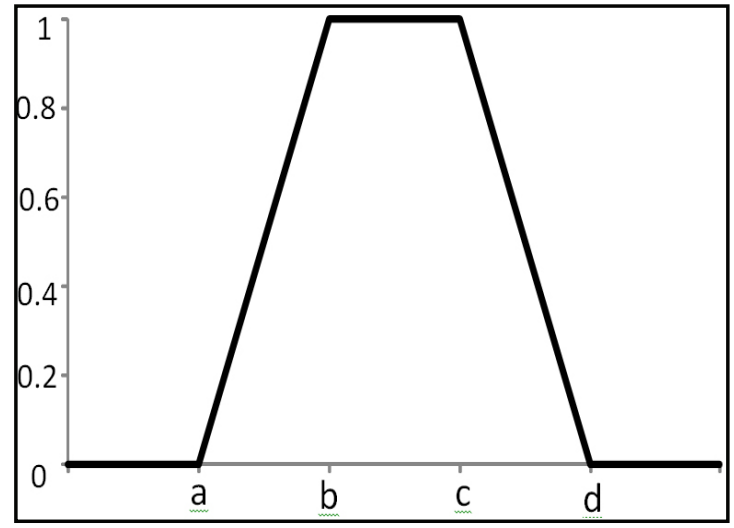

Figure 2: Trapezoidal membership function of fuzzy set
In the fuzzification process empirical data of inputs are transformed into linguistic variables of fuzzy sets. The membership functions are used to associate a grade with each linguistic term. The second part of fuzzy inference systems is IF-THEN rules. The basic fuzzy operations that are used in the antecedent (IF part) and the consequent (THEN part) parts of rules are intersection (AND)

$\mu_{A \cap B}(x)=\mu_{A}(x) \cap \mu_{B}(x)=\min \left(\mu_{A}(x), \mu_{B}(x)\right)$

union (OR)

$\mu_{A \cup B}(x)=\mu_{A}(x) \cup \mu_{B}(x)=\max \left(\mu_{A}(x), \mu_{B}(x)\right)$

and negation (NOT) (Ross, 2004)

$$
\mu_{\bar{A}}(x)=1-\mu_{A}(x) .
$$

The general form of inference rules is given as:

$$
\text { IF } P \text { is } p \text {, THEN } Q \text { is } q \text {, }
$$

where $p$ and $q$ are linguistic terms for linguistic variables $P$ and $Q$, respectively. The fuzzy operator AND is applied in the IF part if it consist of $n$ parts.

$$
\begin{aligned}
& \text { IF }\left(P_{1} \text { is } p_{1} \text { AND } P_{2} \text { is } p_{2} \text { AND } \ldots \text { AND } P_{n} \text { is } p_{n}\right) \\
& \text { THEN } Q \text { is } q,
\end{aligned}
$$

where are linguistic terms for linguistic variables , respectively. Max-min composition, as one of the most commonly used in the Mamdani inference model (Jamshidi et al., 2013; Monjezi \& Rezaei, 2011; Ross, 2004), is applied:

$$
\mu_{C}(\mathrm{z})=\max \left(\min \left(\mu_{A}(x), \mu_{B}(\mathrm{y})\right)\right)
$$

where $\mu_{C}, \mu_{A}, \mu_{B}$ are membership functions of output $z$ and inputs $x$ and $y$, respectively. Finally, the defuzzification process is used to transform fuzzy sets into crisp value. There are several suitable methods in the literature (Gharibi et al., 2012; Ross, 2004). We selected the center 
of maximum technique, which is one of the most frequently used (Joss et al., 2008; Pathak et al., 2005; Ross, 2004). The crisp output is computed as weighted mean of the term membership center points, weighted by the inference results:

$$
x^{*}=\frac{\sum_{k=1}^{n} x_{k} \mu_{C_{k}}(x)}{\sum_{k=1}^{n} \mu_{C_{k}}(x)}
$$

where is defuzzified output, , $\mathrm{k}=1, \ldots, \mathrm{n}$ are aggregated membership functions and , $k=1, \ldots, n$ are output variables (centers of the area).

\section{FUZZY MODEL OF FURNITURE INDUSTRY}

In this section we adopt the general four-stage model for the furniture industry, specifically for kitchen manufacturers. The main purpose of the model is to evaluate the performance level of companies regarding their services associated with sales. Many companies offer a variety of services related to wood. Even companies that are engaged in furniture manufacturing have the option of including various service activities in their offer when marketing their products. This way, they can gain a decisive advantage over their competitors.

To develop the model, in the first stage presales, sales and after-sales services should first be identified. If a wood company has an effective service network, the kitchen buyer will wait for a shorter period of time for its transport and installation - time is a measurable value.

We decided to include the three most often offered pre-sales services in the furniture industry in the model: measurement at home, expert advice and design (3D drawing). Measuring for furniture is certainly high on buyers' list. When measuring the room for new furniture it is not enough to simply measure the size of the room, as windows, fireplaces and doorways should also be taken into account, since these features will influence the placement of the furniture, so expert advice given by someone who has studied a subject thoroughly or who is very skilled at a particular job can be very important. The same can be said for design (3D drawing). All three services can be free or the customer may have to pay fixed percentages of the purchase price. This is also the way that we measured them in the model.
Three sales services that we included in the model are cash discount, interest-free credit and installment sale. A cash discount is an incentive that a seller offers to a buyer in return for paying a bill owed before the scheduled due date. The seller will usually reduce the amount owed by the buyer by a small percentage. Interest-free credit is a credit or loan where no interest is paid by the borrower. Installment sale is a transaction in which the sales price is paid in two or more installments over months or years. In the model, cash discount is measured in percentages, interest-free credit in percentages of the interest rate and installment sale in number of installments.

When buying furniture, customers are often interested in the possibility of delivery and assembly of purchased products, which could be characterized as the most important after-sales services in furniture industry and were, as such, incorporated into the model. We can find many different offers for home delivery of furniture on the market. Some companies offer free delivery of purchased furniture, other companies offer free delivery in a certain area, some companies offer delivery with the price determined by the distance from the store, while some companies simply do not offer such services. Differences between sellers can be found even in furniture delivery to apartments - some sellers offer free delivery to the apartment, while others offer free delivery only to lower floors of apartment buildings and charge for the service otherwise. Similarly, differences between sellers can be found in regard to furniture assembly. Assembling furniture can be a complex and time-consuming process, whether it's a kitchen, cupboard, desk or bookshelf. Unassembled furniture can be difficult to construct, with an assortment of parts, screws, bolts and washers that can be hard to assemble properly. The price the seller offers for furniture assembly is very important. Because of the vast diversity in the offers for these two after-sales services we divided furniture assembly and delivery into two subcategories: free (usually above a fixed amount, measured in euros, where fewer euros signifies a better result) and invoiced (measured in percentages of purchase price). In addition, we added warranty, which is measured in years, to the after-sales services in our model. A warranty is an agreement between the seller and the buyer of furniture to provide repair or replacement for covered components of the product for some specified time period. 


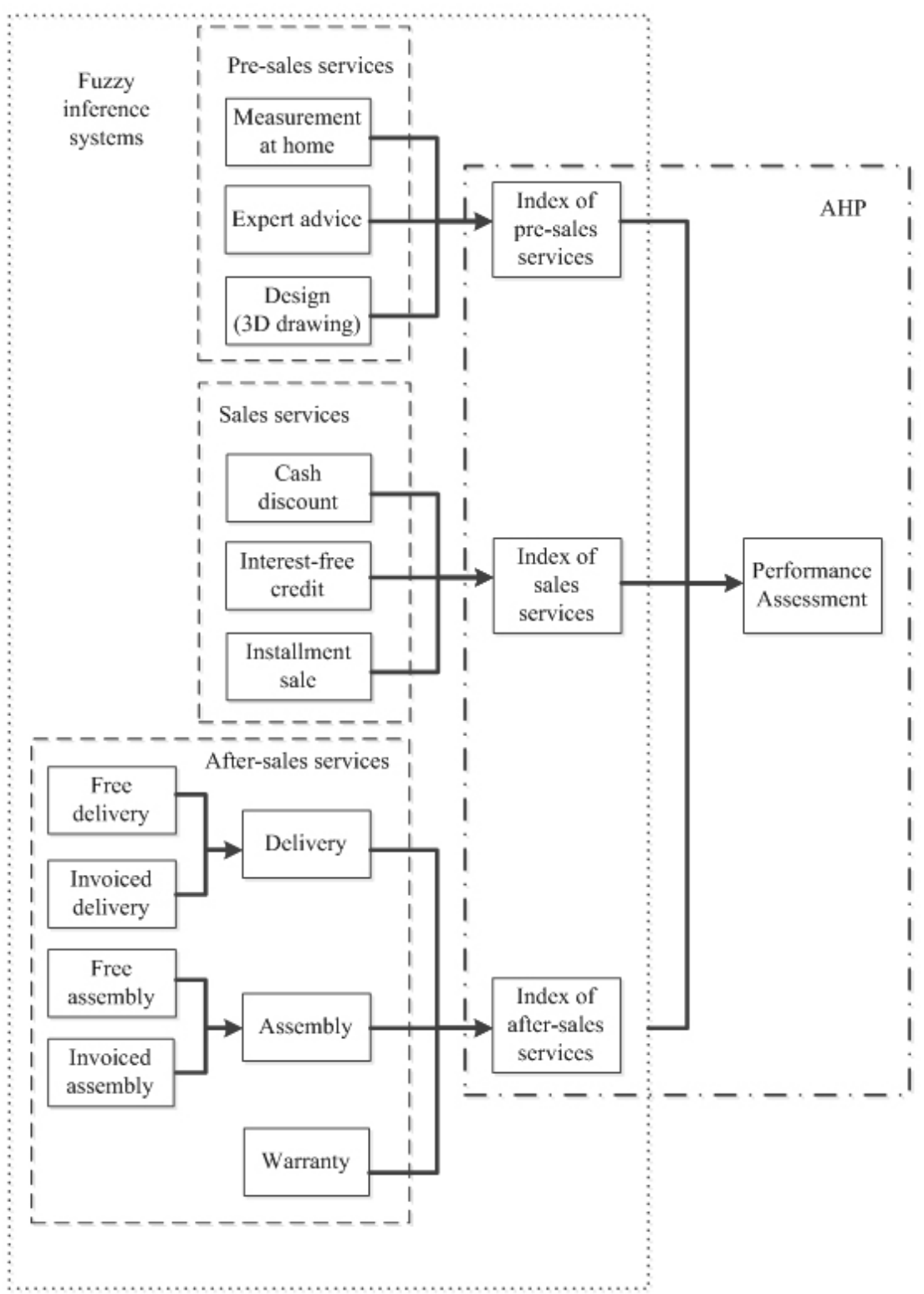

Figure 3: Decision tree of the model for a furniture manufacturing company

The final list of services that can be provided by a furniture manufacturing company to customers and the decision tree of the developed model are presented in Figure 3.

In the second stage, the AHP method was used to compare pre-sales, sales and after-sales services. Twelve marketing experts (managers and academics) from several European countries (Slovenia, Croatia, Poland, Slovakia, Serbia and Macedonia) were selected. The AHP Excel template (Goepel, 2013) was used to perform calculations.

In the third stage, three fuzzy inference systems were built. Their results are indexes of all three groups of services. The first linguistic terms and their membership functions for all services were developed. Usually "the best values" of param- eters of membership functions do not exist and a heuristic approach can be used to set the parameters (Fisher, 2006; Tron \& Margaliot, 2004; Vesely et al., 2016). We defined parameters on the basis of expert knowledge, experience and judgments. We tested similar values of parameters and performed sensitive analysis until we decided that the model's performance was acceptable. Table 1 presents parameters of membership functions in the fuzzy inference system. 
Table 1: Parameters of membership functions in the fuzzy inference system

\begin{tabular}{|c|c|c|c|c|c|c|c|c|c|c|c|c|c|c|c|c|}
\hline \multirow[b]{2}{*}{ Services } & \multirow[b]{2}{*}{ Units } & \multicolumn{4}{|c|}{ poor } & \multicolumn{4}{|c|}{ good } & \multicolumn{4}{|c|}{ very good } & \multicolumn{3}{|c|}{ excellent } \\
\hline & & a & & $b$ & c & a & b & c & $d$ & $a$ & $\begin{array}{l}b \\
d\end{array}$ & c & & & $\begin{array}{l}a \\
c=\end{array}$ & $d^{b}$ \\
\hline Measurement at home & $\%$ & 2.5 & 3 & 5 & 5 & 1 & 1.5 & 2.5 & 3 & 0 & 0 & 1 & 1.5 & & & \\
\hline Expert advice & $\%$ & 2.5 & 3 & 5 & 5 & 1 & 1.5 & 2.5 & 3 & 0 & 0 & 1 & 1.5 & & & \\
\hline Design (3D drawing) & $\%$ & 2.5 & 3 & 5 & 5 & 1 & 1.5 & 2.5 & 3 & 0 & 0 & 1 & 1.5 & & & \\
\hline Cash discount & $\%$ & 0 & 0 & 1 & 2 & 1 & 2 & 4 & 5 & 4 & 5 & 7 & 8 & 7 & 8 & 20 \\
\hline Interest-free credit & $\%$ & 5 & 7 & 15 & 15 & 1 & 3 & poor & 7 & 0 & 0 & 1 & 3 & & & \\
\hline Installment sale & $\begin{array}{l}\text { number of } \\
\text { installments }\end{array}$ & 0 & 0 & 3 & 9 & 3 & 9 & 18 & 24 & 18 & 24 & 48 & 48 & & & \\
\hline Delivery & - & 0 & 0 & 1 & 3 & 1 & 3 & 4 & 6 & 4 & 6 & 7 & 9 & 7 & 9 & 20 \\
\hline Free delivery & euros & 5000 & 5000 & 2500 & 2000 & 2500 & 2000 & 1000 & 500 & 1000 & 500 & 0 & 0 & & & \\
\hline Invoiced delivery & $\%$ & 25 & 25 & 12 & 8 & 12 & 8 & 6 & 2 & 6 & 2 & 0 & 0 & & & \\
\hline Furniture assembly & - & 0 & 0 & 1 & 3 & 1 & 3 & 4 & 6 & 4 & 6 & 7 & 9 & 7 & 9 & 10 \\
\hline Free assembly & euros & 5000 & 5000 & 2500 & 2000 & 2500 & 2000 & 1000 & 500 & 1000 & 500 & 0 & 0 & & & \\
\hline Invoiced assembly & $\%$ & 25 & 25 & 12 & 8 & 12 & 8 & 6 & 2 & 6 & 2 & 0 & 0 & & & \\
\hline Warranty & years & 0 & 0 & 1 & 2 & 1 & 2 & 3 & 5 & 3 & 5 & 10 & 10 & & & \\
\hline Pre-sales services & - & 0 & 0 & 10 & 30 & 10 & 30 & 40 & 60 & 40 & 60 & 70 & 90 & 70 & 90 & 100 \\
\hline Sales services & - & 0 & 0 & 10 & 30 & 10 & 30 & 40 & 60 & 40 & 60 & 70 & 90 & 70 & 90 & 100 \\
\hline After-sales services & - & 0 & 0 & 10 & 30 & 10 & 30 & 40 & 60 & 40 & 60 & 70 & 90 & 70 & 90 & 100 \\
\hline
\end{tabular}

Then inference IF-THEN rules were defined. services. The remaining IF-THEN rules were Table 2 presents IF-THEN rules for pre-sales similarly defined.

Table 2: IF-THEN rules for pre-sales activities

\begin{tabular}{|c|c|c|c|}
\hline \multicolumn{3}{|c|}{ IF part } & \multirow{2}{*}{$\begin{array}{c}\text { THEN part } \\
\text { Pre-sales services }\end{array}$} \\
\hline Measurement at home & Expert advice & $\begin{array}{l}\text { Design } \\
\text { drawing) }\end{array}$ & \\
\hline poor & poor & poor & poor \\
\hline poor & poor & good & poor \\
\hline poor & poor & very good & poor \\
\hline poor & good & poor & poor \\
\hline poor & good & good & good \\
\hline poor & good & very good & good \\
\hline poor & very good & poor & poor \\
\hline poor & very good & good & good \\
\hline poor & very good & very good & very good \\
\hline good & poor & poor & poor \\
\hline good & poor & good & good \\
\hline good & poor & very good & good \\
\hline good & good & poor & good \\
\hline good & good & good & good \\
\hline good & good & very good & very good \\
\hline good & very good & poor & good \\
\hline good & very good & good & very good \\
\hline good & very good & very good & excelent \\
\hline very good & poor & poor & poor \\
\hline very good & poor & good & good \\
\hline very good & poor & very good & very good \\
\hline very good & good & poor & good \\
\hline very good & good & good & very good \\
\hline very good & good & very good & excellent \\
\hline very good & very good & poor & very good \\
\hline very good & very good & good & excellent \\
\hline very good & very good & very good & excellent \\
\hline
\end{tabular}


Finally, parameters for the center of maxima were selected regarding membership functions of groups of services:

$x^{*}=\frac{5 \cdot \mu_{\text {poor }}(x)+35 \cdot \mu_{\text {good }}(x)+65 \cdot \mu_{\text {verygood }}(x)+95 \cdot \mu_{\text {excellent }}(x)}{\mu_{\text {poor }}(x)+\mu_{\text {good }}(x)+\mu_{\text {verygood }}(x)+\mu_{\text {excellent }}(x)}$

The result of falls into the interval and should be normalized (Carbajal-Hernández et al., 2012b) using expression (14) so that the final index takes values in the interval $[0,100]$.

$$
I=100 \cdot \frac{x^{*}-5}{95-5}
$$

Table 3: The inputs for the fuzzy inference system of eight furniture companies

\begin{tabular}{|c|c|c|c|c|c|c|c|c|}
\hline & SI1 & SI2 & HR1 & HR2 & PL1 & PL2 & SK1 & SK2 \\
\hline Measurement at home & $0 \%$ & $0 \%$ & $0 \%$ & $3 \%$ & $2 \%$ & $0 \%$ & $0 \%$ & $2 \%$ \\
Expert advice & $0 \%$ & $0 \%$ & $0 \%$ & $0 \%$ & $0 \%$ & $0 \%$ & $0 \%$ & $0 \%$ \\
Design (3D drawing) & $0 \%$ & $0 \%$ & $0 \%$ & $0 \%$ & $2 \%$ & $0 \%$ & - & $0 \%$ \\
Cash discount & $2 \%$ & $5 \%$ & $5 \%$ & $3 \%$ & $2 \%$ & $7 \%$ & $10 \%$ & $5 \%$ \\
Interest - free credit & - & - & - & $2 \%$ & $1.5 \%$ & $0 \%$ & $1 \%$ & - \\
Installment sale & 6 & - & 6 & 12 & 12 & 48 & 18 & - \\
Free delivery & 1200 & 3000 & 3000 & 0 & 1500 & 5000 & 1500 & 1500 \\
Invoiced delivery & $10 \%$ & $5 \%$ & $5 \%$ & $0 \%$ & $5 \%$ & $2 \%$ & $10 \%$ & $10 \%$ \\
Free assembly & 1200 & 3000 & 3000 & 0 & 0 & 1500 & 1500 & 1500 \\
Invoiced assembly & $10 \%$ & $5 \%$ & $15 \%$ & $0 \%$ & $0 \%$ & $5 \%$ & $15 \%$ & - \\
Warranty & 3 & 4 & 4 & 3 & 5 & 5 & 3 & 5 \\
\hline
\end{tabular}

\section{RESULTS AND DISCUSSION}

The results of the model are presented in Table 4. Weights of AHP comparison of groups of services in sales are written in column 2 . The indexes for
Eight kitchen manufacturers from four European countries (Slovenia (SI1, SI2), Croatia (HR1, HR2), Poland (PL1, PL2) and Slovakia (SK1, SK2)) were selected for model evaluation. The services that they provide are presented in Table 3. The dashes in Table 3 denote that the company does not offer that service. We included this information as the worst possibility in the model.

Table 4: Weights of AHP comparison of groups of services, indexes of all groups of services for all companies, final index of services for all companies and their ranking

\begin{tabular}{|c|c|c|c|c|c|c|c|c|c|}
\hline & $\begin{array}{c}\text { AHP } \\
\text { weights }\end{array}$ & SI1 & SI2 & HR1 & HR2 & PL1 & PL2 & SK1 & SK2 \\
\hline Pre-sales services & 0.392 & 100.0 & 100.0 & 100.0 & 66.7 & 66.7 & 100.0 & 66.7 & 100.0 \\
Sales services & 0.121 & 16.7 & 0.0 & 16.7 & 50.0 & 58.3 & 100.0 & 100.0 & 0.0 \\
After-sales services & 0.487 & 16.7 & 11.1 & 11.1 & 100.0 & 75.0 & 41.7 & 16.7 & 16.7 \\
\hline Final index of services & & $\mathbf{4 9 . 3}$ & $\mathbf{4 4 . 6}$ & $\mathbf{4 6 . 6}$ & $\mathbf{8 0 . 9}$ & $\mathbf{6 9 . 7}$ & $\mathbf{7 1 . 6}$ & $\mathbf{4 6 . 4}$ & $\mathbf{4 7 . 3}$ \\
Ranks & & 4 & 8 & 6 & 1 & 3 & 2 & 7 & 5 \\
\hline
\end{tabular}

By using the AHP method we got the weights for groups of services. Table 4 shows that, according to experts, the most important (AHP weight of 0.487 ) are after-sales services (delivery, furniture assembly and warranty), slightly less impor- all groups of services for eight kitchen manufacturers, which are the results of FIS, are listed in columns 3 to 10. Aggregated results of both methods (final indexes) and the ranking of the kitchen manufacturers are presented in lines 5 and 6 . 
Analysis of eight companies showed that selected companies offer relatively good pre-sales services. Five of the eight analyzed companies in the light of these services reached the maximum index. Companies have achieved much worse ratings in terms of sales and after-sales services. Only one company (HR2) reached the maximum score in terms of after-sales services, while all the others achieved very low ratings. Due to the low ratings of after-sales services, the final indexes of services are rather low. The highest final index of services (HR2) was 80.8 and the lowest (SI2) was 44.6.

The results indicate that the model can show companies a general evaluation of each group of their services. The company can compare performances between groups of its services. It can also compare its results with other competitive companies. Such a comparison can give the company a good starting point for improving its services. From the results, the company can see which services it should emphasize to gain the largest benefit. AHP weights have a significant influence on the final ranking so they should be carefully performed. The model is also very appropriate for ranking the evaluated companies as it can perceive small differences between the evaluations. In conclusion, we can say that the model is suitable for determining the quality of services in furniture manufacturing companies and with small modifications it could also be used for assessment services in enterprises from other industries.

\section{CONCLUSIONS}

In the paper we presented a model that allows us to evaluate and analyze individual furniture manufacturing companies in terms of service provision. The model we developed is based on two methods, namely the method of multicriteria decision-making, AHP, and a fuzzy logic inference decision system. In a specific model for furniture companies all services that are important for potential customers were included in the decision tree. Then we determined parameters of membership functions and defined rules of decision (IF-THEN), which represent all needed data for FIS. We obtained the information for model testing from eight kitchen manufacturers from four European countries. It turned out that by using the model, we can accurately determine the performance of manufacturing companies in terms of service provision. At the same time, the model enables analysis of individual services. This means that it can also be used as a tool for strategy formulation for service activities in the company. The general model is not only usable in the furniture industry, but can be used in other industries as well. In future work, analysis of services regarding different groups of customers (Ahn \& Sohn, 2009) and sensitivity analysis of parameters in the model could be carried out.

\section{REFERENCES}

1) Afrinaldi, F., \& Zhang, H.-C. (2014). A fuzzy logic based aggregation method for life cycle impact assessment. Journal of Cleaner Production, 67, 159-172.

2) Ahmad, S., \& Butt, M. M. (2012). Can after sale service generate brand equity? Marketing Intelligence \& Planning, 30(3), 307-323.

3) Ahn, J. S., \& Sohn, S. Y. (2009). Customer pattern search for after-sales service in manufacturing. Expert Systems with Applications, 36(3, Part 1), 5371-5375.

4) Alzola, L. M., \& Robaina, V. P. (2010). The impact of pre-sale and post-sale factors on online purchasing satisfaction: A survey. International Journal of Quality \& Reliability Management, 27(2), 121-137.

5) Ananda, J., \& Herath, G. (2003). The use of analytic hierarchy process to incorporate stakeholder preferences into regional forest planning. Forest Policy and Economics, 5(1), 13-26.

6) Brady, M. K., \& Cronin, J. J. J. (2001). Some new thoughts on conceptualizing perceived service quality: A hierarchical approach. Journal of Marketing, 65(3), 34-49.

7) Brax, S. (2005). A manufacturer becoming service provider - Challenges and a paradox. Managing Service Quality: An International Journal, 15(2), 142-155.

8) Buera, F. J., \& Kaboski, J. P. (2012). The rise of the service economy. American Economic Review, 102(6), 2540-2569.

9) Camastra, F., Ciaramella, A., Giovannelli, V., Lener, M., Rastelli, V., Staiano, A., . . Starace, A. (2015). A fuzzy decision system for genetically modified plant environmental risk assessment using Mamdani inference. Expert Systems with Applications, 42(3), 1710-1716. 
10) Carbajal-Hernández, J. J., Sánchez-Fernández, L. P., Carrasco-Ochoa, J. A., \& Martínez-Trinidad, J. F. (2012a). Assessment and prediction of air quality using fuzzy logic and autoregressive models. Atmospheric Environment, 60, 37-50.

11) Carbajal-Hernández, J. J., Sánchez-Fernández, L. P., Carrasco-Ochoa, J. A., \& MartínezTrinidad, J. F. (2012b). Immediate water quality assessment in shrimp culture using fuzzy inference systems. Expert Systems with Applications, 39(12), 10571-10582.

12) Carreño, M. L., Cardona, O. D., \& Barbat, A. H. (2011). New methodology for urban seismic risk assessment from a holistic perspective. Bulletin of Earthquake Engineering, 10(2), 547-565.

13) Chai, J., Liu, J. N. K., \& Ngai, E. W. T. (2013). Application of decision-making techniques in supplier selection: A systematic review of literature. Expert Systems with Applications, 40(10), 3872-3885.

14) Chang, P.-C., \& Liu, C.-H. (2008). A TSK type fuzzy rule based system for stock price prediction. Expert Systems with Applications, 34(1), 135-144.

15) Che Osmi, S. F., Malek, M. A., Yusoff, M., Azman, N. H., \& Faizal, W. M. (2016). Development of river water quality management using fuzzy techniques: A review. International Journal of River Basin Management, $1-12$.

16) Cronin Jr, J. J., \& Taylor, S. A. (1992). Measuring service quality: A reexamination and extension. Journal of Marketing, 56(3), 5568.

17) Donevska, K. R., Gorsevski, P. V., Jovanovski, M., \& Peševski, I. (2011). Regional non-hazardous landfill site selection by integrating fuzzy logic, AHP and geographic information systems. Environmental Earth Sciences, 67(1), 121-131.

18) Fazlzadeh, A., Bagherzadeh, F., \& Mohamadi, P. (2011). How after-sales service quality dimensions affect customer satisfaction. African Journal of Business Management, 5(17), 7658-7664.

19) Fisher, B. E. A. (2006). Fuzzy approaches to environmental decisions: Application to air quality. Environmental Science \& Policy, 9(1), 22-31.
20) Frei, F. X. (2008). The four things a service business must get right. Harvard business review, 86(4), 70-80, 136.

21) Gaiardelli, P., Saccani, N., \& Songini, L. (2007). Performance measurement of the after-sales service network: Evidence from the automotive industry. Computers in Industry, 58(7), 698-708.

22) Gharibi, H., Mahvi, A. H., Nabizadeh, R., Arabalibeik, H., Yunesian, M., \& Sowlat, M. H. (2012). A novel approach in water quality assessment based on fuzzy logic. Journal of Environmental Management, 112, 87-95.

23) Godley, A. C. (2013). Entrepreneurial opportunities, implicit contracts, and market making for complex consumer goods. Strategic Entrepreneurship Journal, 7(4), 273-287.

24) Goepel, K. D. (2013). Implementing the analytic hierarchy process as a standard method for multi-criteria decision making in corporate enterprises - a new AHP Excel template with multiple inputs. Paper presented at the International Symposium on the Analytic Hierarchy Process, Kuala Lumpur.

25) Grönroos, C., \& Ojasalo, K. (2004). Service productivity: Towards a conceptualization of the transformation of inputs into economic results in services. Journal of Business Research, 57(4), 414-423.

26) Gummesson, E. (1991). Truths and myths in service quality. International Journal of Service Industry Management, 2(3), 7-16.

27) Gummesson, E. (1998). Productivity, quality and relationship marketing in service operations. International Journal of Contemporary Hospitality Management, 10(1), 4-15.

28) Gummesson, E. (2014). Productivity, quality and relationship marketing in service operations: A revisit in a new service paradigm. International Journal of Contemporary Hospitality Management, 26(5), 656-662.

29) Ho, W., Xu, X., \& Dey, P. K. (2010). Multi-criteria decision making approaches for supplier evaluation and selection: A literature review. European Journal of Operational Research, 202(1), 16-24.

30) Hoekman, B., \& Mattoo, A. (2012). Services trade and growth. International Journal of Services Technology and Management, 17(2-4), 232-250. 
31) Jamshidi, A., Yazdani-Chamzini, A., Yakhchali, S. H., \& Khaleghi, S. (2013). Developing a new fuzzy inference system for pipeline risk assessment. Journal of Loss Prevention in the Process Industries, 26(1), 197-208.

32) Johnson, M. D., Gustafsson, A., Andreassen, T. W., Lervik, L., \& Cha, J. (2001). The evolution and future of national customer satisfaction index models. Journal of Economic Psychology, 22(2), 217-245.

33) Jones, P. (1988). Quality, capacity and productivity in service industries. International Journal of Hospitality Management, 7(2), 104-112.

34) Joss, B. N., Hall, R. J., Sidders, D. M., \& Keddy, T. J. (2008). Fuzzy-logic modeling of land suitability for hybrid poplar across the Prairie Provinces of Canada. Environmental Monitoring and Assessment, 141(1-3), 79-96.

35) Juang, Y.-S., Lin, S.-S., \& Kao, H.-P. (2007). Design and implementation of a fuzzy inference system for supporting customer requirements. Expert Systems with Applications, 32(3), 868-878.

36) Kasper, H., \& Lemmink, J. (1989). After sales service quality: Views between industrial customers and service managers. Industrial Marketing Management, 18(3), 199-208.

37) Koul, S., \& Verma, R. (2011). Dynamic vendor selection based on fuzzy AHP. Journal of Manufacturing Technology Management, 22(8), 963-971.

38) Kovac, P., Rodic, D., Pucovsky, V., Savkovic, B., \& Gostimirovic, M. (2012). Application of fuzzy logic and regression analysis for modeling surface roughness in face milliing. Journal of Intelligent Manufacturing, 24(4), 755-762.

39) Lima Junior, F. R., Osiro, L., \& Carpinetti, L. C. R. (2013). A fuzzy inference and categorization approach for supplier selection using compensatory and non-compensatory decision rules. Applied Soft Computing, 13(10), 4133-4147.

40) Luzon, B., \& El-Sayegh, S. M. (2016). Evaluating supplier selection criteria for oil and gas projects in the UAE using AHP and Delphi. International Journal of Construction Management, 16(2), 175-183.

41) Mamdani, E. H., \& Assilian, S. (1975). An experiment in linguistic synthesis with a fuzzy logic controller. International Journal of ManMachine Studies, 7(1), 1-13.

42) McLaughlin, C. P., \& Coffey, S. (1990). Measuring productivity in services. International Journal of Service Industry Management, 1(1), 46-64.

43) Monjezi, M., \& Rezaei, M. (2011). Developing a new fuzzy model to predict burden from rock geomechanical properties. Expert Systems with Applications, 38(8), 9266-9273.

44) Murali, S., Pugazhendhi, S., \& Muralidharan, C. (2016a). Assessment of impact of after sales service attributes on customer satisfaction for a home-appliances manufacturing firm. International Journal of Enterprise Network Management, 7(1), 27-41.

45) Murali, S., Pugazhendhi, S., \& Muralidharan, C. (2016b). Modelling and investigating the relationship of after sales service quality with customer satisfaction, retention and loyalty - A case study of home appliances business. Journal of Retailing and Consumer Services, 30, 67-83.

46) Muyeed, M. A. (2012). Customer perception on service quality in retail banking in developing countries - A case study. International Journal of Marketing Studies, 4(1), 116-122.

47) Nabavi, V., Azizi, M., \& Faezipour, M. (2014). Implementation of quality management system based on ISO9001:2008 and its effects on customer satisfaction case study: Kitchen worktops factory. International Journal of Quality \& Reliability Management, 31(8), 921-937.

48) Nadali, A., Kakhky, E. N., \& Nosratabadi, H. E. (2011, 8-10 April 2011). Evaluating the success level of data mining projects based on CRISP-DM methodology by a Fuzzy expert system. Paper presented at the Electronics Computer Technology (ICECT), 2011 3rd International Conference

49) Nilashi, M., Zakaria, R., Ibrahim, O., Majid, M. Z. A., Mohamad Zin, R., Chugtai, M. W., . . Aminu Yakubu, D. (2015). A knowledgebased expert system for assessing the performance level of green buildings. Knowledge-Based Systems, 86, 194-209.

50) Noorul Haq, A., \& Kannan, G. (2006). Fuzzy analytical hierarchy process for evaluating and selecting a vendor in a supply chain model. The International Journal of Advanced 
Manufacturing Technology, 29(7), 826-835.

51) Ocampo-Duque, W., Ferré-Huguet, N., Domingo, J. L., \& Schuhmacher, M. (2006). Assessing water quality in rivers with fuzzy inference systems: A case study. Environment International, 32(6), 733-742.

52) Pakdil, F., Işın, F. B., \& Genç, H. (2012). A quality function deployment application using qualitative and quantitative analysis in after sales services. Total Quality Management \& Business Excellence, 23(11-12), 1397-1411.

53) Pathak, J., Vidyarthi, N., \& Summers, S. L. (2005). A fuzzy - based algorithm for auditors to detect elements of fraud in settled insurance claims. Managerial Auditing Journal, 20(6), 632-644.

54) Pezdevšek Malovrh, Š., Kurttila, M., Hujala, T., Kärkkäinen, L., Leban, V., Lindstad, B. H., . . Krč, J. (2016). Decision support framework for evaluating the operational environment of forest bioenergy production and use: Case of four European countries. Journal of Environmental Management, 180, 68-81.

55) Posselt, T., \& Gerstner, E. (2005). Pre-sale vs. post-sale e-satisfaction: Impact on repurchase intention and overall satisfaction. Journal of Interactive Marketing, 19(4), 35-47.

56) Ratnayake, R. M. C. (2014). Application of a fuzzy inference system for functional failure risk rank estimation: RBM of rotating equipment and instrumentation. Journal of Loss Prevention in the Process Industries, 29, 216-224.

57) Rigopoulou, I. D., Chaniotakis, I. E., Lymperopoulos, C., \& Siomkos, G. I. (2008). After-sales service quality as an antecedent of customer satisfaction: The case of electronic appliances. Managing Service Quality: An International Journal, 18(5), 512-527.

58) Rodríguez, A., Ortega, F., \& Concepción, R. (2016). A method for the evaluation of risk in IT projects. Expert Systems with Applications, 45, 273-285.

59) Ross, T. J. (2004). Fuzzy logic with engineering applications. New York: Wiley.

60) Saaty, T. L. (1980). The analytic hierarchy process. New York: McGraw-Hill.

61) Saaty, T. L. (2006). Fundamentals of decision making and priority theory with the analytic hierarchy process. Pittsburgh: RWS Publications.
62) Saaty, T. L., \& Ozdemir, M. S. (2003). Why the magic number seven plus or minus two. Mathematical and Computer Modelling, 38(34), 233-244.

63) Saaty, T. L., \& Peniwati, K. (2008). Group decision making: Drawing out and reconciling differences. Pittsburgh, PA: RWS Publications.

64) Saaty, T. L., \& Vargas, L. G. (2007). Dispersion of group judgments. Mathematical and Computer Modelling, 46(7-8), 918-925.

65) Saccani, N., Songini, L., \& Gaiardelli, P. (2006). The role and performance measurement of after-sales in the durable consumer goods industries: An empirical study. International Journal of Productivity and Performance Management, 55(3/4), 259-283.

66) Sahay, B. S. (2005). Multi-factor productivity measurement model for service organisation. International Journal of Productivity and Performance Management, 54(1), 7-22.

67) Santouridis, I., \& Trivellas, P. (2010). Investigating the impact of service quality and customer satisfaction on customer loyalty in mobile telephony in Greece. The TQM Journal, 22(3), 330-343.

68) Schembri, S., \& Sandberg, J. (2002). Service quality and the consumer's experience: Towards an interpretive approach. Marketing Theory, 2(2), 189-205.

69) Shaharudrn, M. R., Yusof, K. M. M., Elias, S. J., \& Mansor, S. W. (2009). Factors affecting customer satisfaction in after-sales service of Malaysian electronic business market. Canadian Social Science, 5(6), 10-18.

70) Shahrouzifard, S., \& Faraji, M. (2016). After-sales service quality as an antecedent of customer satisfaction. Accounting, 2(2), 81-84.

71) Sowlat, M. H., Gharibi, H., Yunesian, M., Tayefeh Mahmoudi, M., \& Lotfi, S. (2011). A novel, fuzzy-based air quality index (FAQI) for air quality assessment. Atmospheric Environment, 45(12), 2050-2059.

72) Sun, K.-A., \& Kim, D.-Y. (2013). Does customer satisfaction increase firm performance? An application of American Customer Satisfaction Index (ACSI). International Journal of Hospitality Management, 35, 68-77. 
73) Tron, E., \& Margaliot, M. (2004). Mathematical modeling of observed natural behavior: a fuzzy logic approach. Fuzzy Sets and Systems, 146(3), 437-450.

74) Vesely, S., Klöckner, C. A., \& Dohnal, M. (2016). Predicting recycling behaviour: Comparison of a linear regression model and a fuzzy logic model. Waste Management, 49, 530-536.

75) Wang, F.-K., Chang, K.-K., \& Tzeng, C.-W. (2011). Using adaptive network-based fuzzy inference system to forecast automobile sales. Expert Systems with Applications, 38(8), 10587-10593.

76) Yadav, V., \& Sharma, M. K. (2015). Multi-criteria decision making for supplier selection using fuzzy AHP approach. Benchmarking: An International Journal, 22(6), 1158-1174.

77) Zadeh, L. A. (1965). Fuzzy sets. Information and Control, 8(3), 338-353.
78) Zani, S., Milioli, M. A., \& Morlini, I. (2013). Fuzzy composite indicators: An application for measuring customer satisfaction. In $\mathrm{N}$. Torelli, F. Pesarin \& A. Bar-Hen (Eds.), Advances in theoretical and applied statistics (pp. 243-253). Berlin, Heidelberg: Springer Berlin Heidelberg.

79) Zavadskas, E. K., \& Turskis, Z. (2011). Multiple criteria decision making (MCDM) methods in economics: an overview. Technological and Economic Development of Economy, 17(2), 397-427.

80) Zeithaml, V. A. (2000). Service quality, profitability, and the economic worth of customers: What we know and what we need to learn. Journal of the Academy of Marketing Science, 28(1), 67-85.

Paper sent to revision: 08.03.2017.

Paper ready for publication: 26.07.2017. 